\title{
衝撃荷重時における膝半月板組織の変形挙動とショック吸収機能*
}

\author{
小 林 正 典*1, 小 林 正 治*2
}

\section{Study on the Shock-Absorption and Deformation of Meniscus under the Impact Loading Condition}

\author{
Masanori KOBAYASHI*3 and Masaharu KOBAYASHI \\ ${ }^{* 3}$ Department of Mechanical Engineering, Daido University, \\ 10-3 Takiharu-cho, Minami-ku, Nagoya-shi, Aichi, 457-8530 Japan
}

\begin{abstract}
Although many biomechanical studies have been addressed the shock absorption function of menisci on a knee joint, few reports concerning the behavior of menisci under the impact loading condition are presented. In this study, the impact compression test using the normal porcine knee joint was performed in order to observe the visco-elastic behavior of the meniscus by the high-speed video camera. As a result, the normal meniscus showed the typical visco-elastic property under the high strain rate of meniscus for the dynamic stress. This fact indicated the meniscus could not possess excellent shock-absorbing against the high impact energy to knee joint.
\end{abstract}

Key Words: Impact Loading Condition, Meniscus, Visco-Elasticity, High-Speed Video Camera

\section{1. 緒音}

人体の㬵関節内にある半月板組織は, 過去の数々の バイオメカニクスの研究から，関節衝撃時の緩和機能 を持つとされている(1). しかしながら，半月板の組織 はコラーゲン線維を中心にプロテオグリカンや水分を 含有する繊維軟骨であり，その粘弾性特性から衝撃時 には強い抵抗を持つとも考えられる。しかしながら shock-absorptionに対応子る半月板の変形挙動につ いては，肉眼的にまだ十分に確認されていない。

そこで本研究では，高速度力メラを用いて衝撃荷重 時の豚の膝関節を撮影し半月板の変形挙動を観察・検 討を行った。

\section{2. 実験方法および結果}

$2 \cdot 1$ 実験試料と装置本実験に用いた実験装置 およびう法の概略を図 1 に示す。

衝撃試験には，落鍾式衝撃試験装置を使用した。装

* 原稿受付 2009 年 5 月 8 日.

*1 正員, 大同大学工学部機械工学科(西457-8530 名古屋市南 区滝春町 $10-3$ ).

*2 正員, 大同大学大学院工学研究科.

E-mail : mkoba@daido-it.ac.jp
置の構造は長さ $1600 \mathrm{~mm} の \mathrm{H}$ 型鋼 $(125 \times 125 \times \mathrm{t} 6.5$ $\mathrm{mm}$ )を組み合わせて土台とし，その中央部に試料を 設置するための正四面体状の空間を設け，その鉛直上 に錘を舁降させるためのシームレスパイプを垂直に固 定した。また，シームレスパイプ上端に滑車を取り付 け，手動ウインチを用いてワイヤを巻くことで鏵の落 下距離を任意に調節できる構造とした。錘は，一般構 造用压延鋼材 (SS 400)で, 直径 $130 \mathrm{~mm}$, 高さ 100 $\mathrm{mm}$, 重さ $10 \mathrm{~kg}$ の円柱形でりイヤに直結している.

図 1 のように衝撃時の反動を予防し錘が試料に重直 に荷重がかかるように作製した治具にブ夕の滕関節試

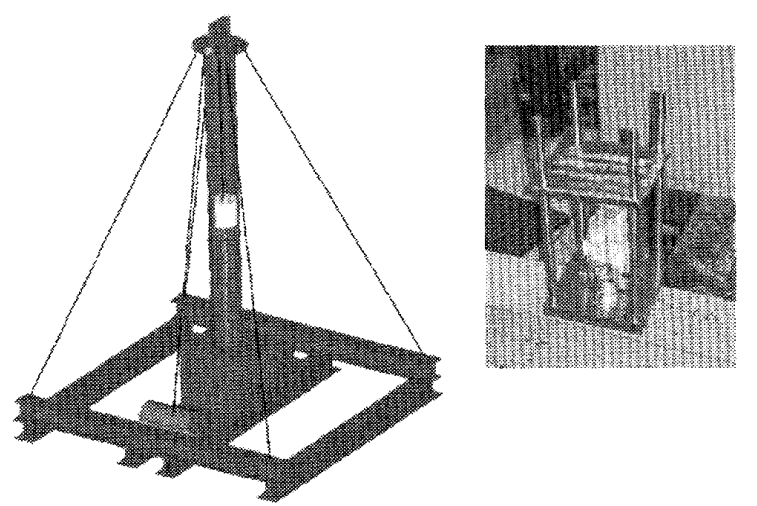

Fig. 1 Impaction test machine and sample 
料在固定した後，この落鍾式衝撃試験装置を用いて膝 関節試料に衝撃荷重を加え, その時の半月板の挙動を ハイスピードデジタルカメラによって撮影した。

$2 \cdot 2$ 撮影条件本実験ではヒトが日常生活で頻 繁汇利用しうる階段昇降を想定して, 階段の 1 step 分 の高さ $(0.20 \mathrm{~m})$ で平均体重 $60 \mathrm{~kg}$ のヒトの片脚立位 時をする時の位置エネルギー $30 \times 9.81 \times 0.20 \div 60$ $\mathrm{N} \cdot \mathrm{m}$ を基準に, 実際のブタ㯟関節の大きさ等を考慮 して，その部分荷重となる $1 / 2,1 / 3$ を荷重值として設 定した。

表 1 に加えた錘の落下距離と位置エネルギーの簡単 な物理関係 $E=m g h=1 / 2 m v^{2}(m$ は体重 $[\mathrm{kg}], g$ は 重力加速度 $9.81 \mathrm{~m} / \mathrm{s}^{2}, h$ は落下距離) 加ら求めた位置 エネルギーと衝突時の落下速度 $V[\mathrm{~m} / \mathrm{s}]$ を示す.

本実験で用意したカメラの本実験での録画速度は $5000 \mathrm{pps}$ とした．録画速度 $5000 \mathrm{pps}$ 時の有効画素数 は $512 \times 500$ の 256000 pixel, 有効撮影範囲は $8.2 \times$ $6.2 \mathrm{~mm}$ である.撮影時間は衝撃荷重が加わった瞬間 から $0.03 \mathrm{~s}$ までとした。

$2 \cdot 3$ 計測方法 画像解析ソフトを用いて impact 時からの半月板の愿さ変化 (impact 付与前にそれぞれ が持つ初期厚さからの变化量) を経時的に観察した(図 2).

$\mathbf{2 \cdot 4}$ 実験結果 図 3 にカメラで撮影した半月板 の衝撃荷重時の経時的変形挙動を示す.

図 4 にこの画像から得られた位置エネルギーとその 時の大眼骨顆部最下端での半月板の変形率 $(=$ 変形量/ もとの厚み) との関係 $(\mathrm{a})$, 半月板の最大変形までの 到達速度と位置エネルギーとの関係 ( b ) を示寸。

この実験では，半月板の水平方向への滑りや関節下

Table 1 Experimental impaction energy conditions

\begin{tabular}{|c|c|c|}
\hline Fall $[\mathrm{m}]$ & Energy $[\mathrm{N} \cdot \mathrm{m}]$ & $\mathrm{V}_{\mathrm{i}}[\mathrm{m} / \mathrm{s}]$ \\
\hline 0.2 & $\fallingdotseq 20$ & $\doteqdot 2.0$ \\
\hline 0.4 & $\fallingdotseq 40$ & $\doteqdot 2.8$ \\
\hline 0.6 & $\doteqdot 60$ & $\doteqdot 3.5$ \\
\hline
\end{tabular}

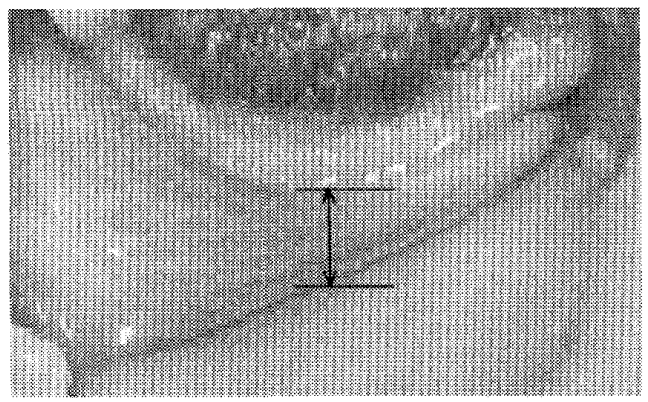

Fig. 2 Measure point of specimen
の海綿骨の変形もあるため, 確実な評価は難しいが, 全体的に位置エネルギーが高くなっても半月板のひず み量はあまり増大せず，位置エネルギーの増大につれ
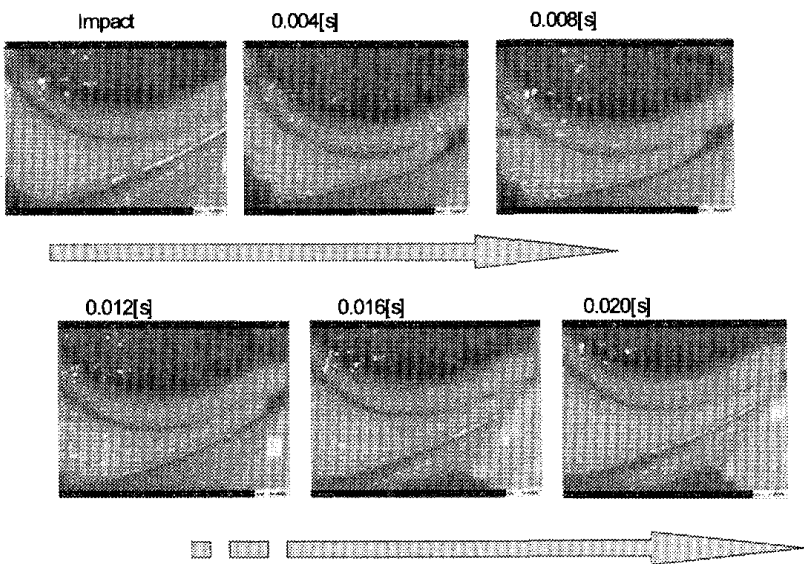

Fig. 3 Images of meniscus deformation under the impact loading

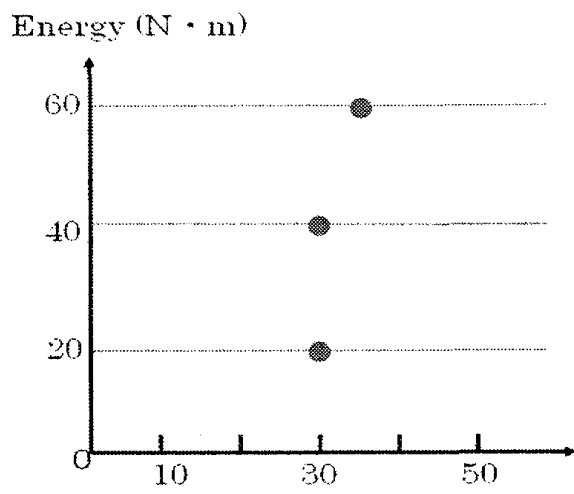

The amount of maximum strain of meniscus thickness

(a) The correlation between impaction energy and strain of meniscus

Strain rate of

meniscus

thickness $(\mathrm{m} / \mathrm{s})$

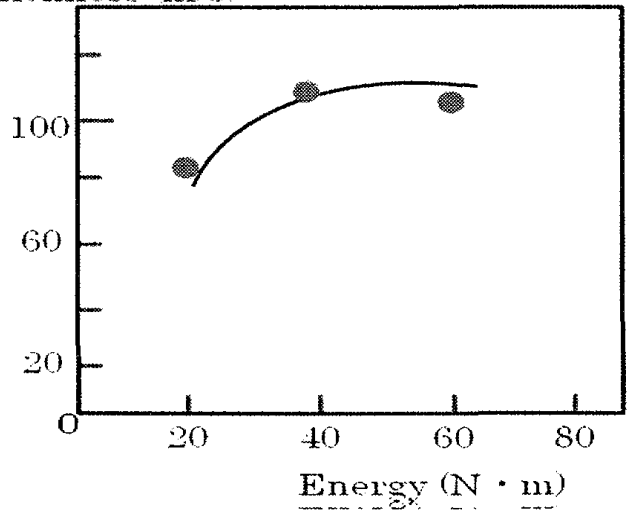

(b) The correlation between impaction energy and strain rate of meniscus

Fig. 4 The correlation between impaction energy and mechanical properties of meniscus 


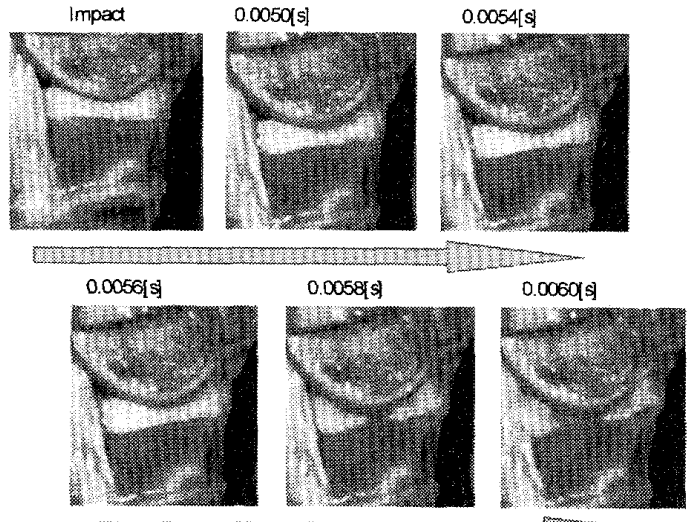

a

Fig. 5 The image of meniscus rupture case

て観測された半月板のひずみ速度の増加量も停滞して いく傾向が見られた。

また，図 5 に実験中 1 例に見られた半月板断裂の画 像を示亦。この症例で注他の試料以上に半月板の水平 方向への移動が少なく，圧縮方向の半月板の厚为が注 とんど変化しないまま脆性破断した。

\section{3. 考察および結論}

半月板組織が関節運動の安定化や潤滑機能の保持な ど数々の生体力学的機能を持つことは基礎研究から明 らかになっており ${ }^{(2)}$, 膝関節への衝擊緩和機能もまた， スポーツ学分野や臨床も含めた整形外科分野では一般 的に受け入れられている(3).

しかしながら，半月板の組織はコラーゲン線維を中 心にプロテオグリカンや水分を含有するグル状の高分 子材料である。このような材料に見られる特有のレオ ロジー特性として, 既に Maxwell モデルやVoigt モ デルで説明されているように(4), 衝撃荷重時すなわち, ひずみ速度 $\mathrm{d} \gamma / \mathrm{d} t$ が大きい時に変形に要する力は，以 下の粘性則の項 $S$ が大きく影響して

$$
S=\eta \cdot \frac{\mathrm{d} \gamma}{\mathrm{d} t} \quad(\eta: \text { 粘性率 })
$$

高い弾性率および抵抗力を持つことになる。このこと は, 強い衝撃荷重時の半月板は shock-absorption と して機能しないばかりか, むしろ相効する関節軟骨に 大きな反力をかける結果につながることを示唆してい 万.

高ひずみ速度時の半月板自体の粘弾性挙動のデータ は今まで報告されていなかったが，今回の実験結果で は, 半月板の変形がこのレオロジー理論に従った機械 的特性を示すことが初めて確認された。

過去の半月板の衝撃吸収機能を報告した研究は, In vitro, In vivo 含めて多くは, 㯟関節遠位での荷重計 測や床反力を観測したものであり，海綿骨や軟骨など 他の組織が関与している可能性が高いと考えられる. この衝撃実験でも, 膝関節試料下での衝撃值を計測し たが，上記の半月板以外の組織の穖械的性質やせん断 方向への半月板のすべりが複雑に関与するため, 半月 板にかかる衝撃と計測数値との関係の解析はまだ十分 でない.しかしながら,この画像観察結果からは, 半 月板がどのような環境下でも十分な衝撃荷重の緩和機 能を有しているわけではなく，スポーツ活動などの溙 関節衝撃による半月板損傷や変形性膝関節症の発症入 カニズムに大きく関与している可能性が推察された。

\section{文献}

(1) Voloshin, A.S. and Wosk, J., Shock absorption of meniscectomized and painful knees: a comparative in vivo study, J. Biomed. Eng., Vol. 5 (1983), pp. 157-161.

(2) Brindle, T., Nyland, J. and Johnson, D. L., The meniscus: Review of Basic Principles with Application to Surgery and Rehabilitation, J. Athletic Training, Vol. 36 (2001), pp. 160-169.

(3) Hirohata, K. and Terayama, K., Standard Textbook Orthopedics Surgery, Vol. 4 (1990), pp. 491-492. Igakushoin.

(4) Murakami, K., Basic Rheology, JSME Date Hand book: Heat Transfer, (1998), pp. 75-145, Sangyotosyo. 